\title{
The Impacts of Arctic Passages Opening on China's International Shipping
}

\author{
Yiying Liu ${ }^{\mathrm{a}}$, Qiqi Zhao ${ }^{\mathrm{b}}$, Houming Fan ${ }^{\mathrm{c}}$ and Xi Yao ${ }^{\text {* }}$ \\ Transportation Management College, Dalian Maritime University, Dalian, China \\ aliuyiying976@163.com, bannanaqq@163.com, cfhm468@163.com, dyaoxi_909@163.com
}

Keywords: Arctic passage; International shipping; Container shipping; Crude oil shipping; Bulk shipping

\begin{abstract}
Aiming at the natural features and assisting navigation status on the Arctic routes, the impacts of Arctic shipping on China's container shipping, crude oil import shipping and bulk cargo shipping are analyzed. It is concluded that the Arctic navigation will reduce the shipping cost. The economic potential it brings will make a positive impact on the international shipping between China-Europe, and China-eastern America. With the further melting of the Arctic ice, assisting navigation's cost can be reduced or even canceled. And the rapid development of navigation technology, the shipbuilding technology will make Arctic routes the important link among China, the United States and Europe.
\end{abstract}

\section{Introduction}

Climate warming makes the Arctic routes gradually opened and may become the main routes between North-western Europe and East Asia, which will have important effects on the future structure of the world shipping.

The Arctic routes are the navigation channels which connect the Atlantic and Pacific oceans via the Arctic Ocean. As is shown in Fig. 1, it includes the Northeast Passage (NEP), the Northwest Passage (NWP) and the North Passage.

All of the three channels are located within the Arctic Circle. Their natural environments are similar, but still have big distinctions which change over time and region. For example, the visibility in summer is very low because of the fog, while the winter storm brings risks and complexity for the navigation of ships [1].

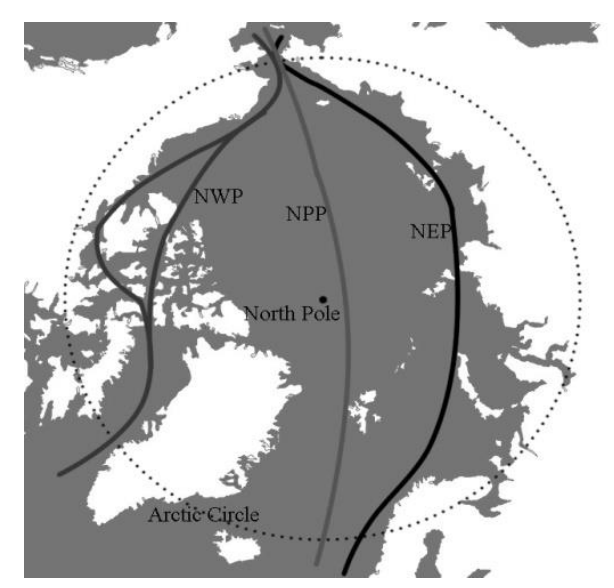

Figure 1. The Schematic diagram of three Arctic channels

(1) The NEP runs across the edge of the Arctic sea from west to east through the Kara, Laptev Sea, the East Siberian Sea and the Chukchi Sea in sequence. The segment from Nordic to Kara has been opened to navigation all of the year. The climate condition of the other sea areas is severe. The winter is severe and long, and filled with the storm weather; the ocean surface humidity is big in summer, and the visibility is very low because of the fog. The temperature rises fast from the 
middle of July to the middle of September, and the ice melt gradually to suit for the passage of the ship. Because this segment is located in Russia's Shoreline extension, Russia charges for the ships due to its assistance compulsively. For example, the icebreaker escort fee was $\$ 160,000$ when "Yong Sheng" ship ran across the NEP in August 2013 [2]. At present, Russian authorities want to improve the efficiency of the NEP through establishing the cost of pilot according to the number of pilot area and the period to determine.

(2) The NWP refers to the Bering Strait as the starting point, to east offshore waters of Northern Alaska, through the Canadian Arctic islands, until Davis Strait, across the length of more than 2900 $\mathrm{nm}$. The NWP can be roughly divided into three segments: the first is from Bering Strait to the Beaufort Sea; the second is from Canada's northern Arctic Archipelago, the third is from Baffin Bay to Davis Strait. The key that the NWP can be opened to navigation is Canada's northern Arctic islands. For comparison, the Bering Strait, the Beaufort Sea, Baffin Bay, Davis Strait can be achieved navigation in July.

The North Passage refers to from the Bering Strait, not through Russia or coast of North America, but directly through the North Pole area reached Greenland Sea or Norwegian Sea. Due to the Arctic Ocean center area is covered with many years accumulation of sea ice, where the sea ice is the densest and most thick, there is no passage for the ship. Because the North passage is covered by ice and snow all the year round, is generally given priority to the scientific investigation ship, with no commercial ship to voyage, so this paper mainly discusses the NEP and NWP.

\section{The Influence of the Arctic Navigation for Container Shipping}

In the foreign trade of China, Sino-European trade occupies an important position in the trade. The European Union has kept China as the largest trading partner for more than ten years in a row. The form to reach the trade in goods is giving priority to container shipping. In 2013, Asia and Europe's seaborne volume of container had reached 19.846 million TEU [3]. The Arctic navigation has an important influence on ship routes. The navigation of NEP will shorten the voyage from East Asia to Northwestern Europe, such as the voyage from Shanghai to Hamburg. If we go across the Suez Canal Shipping Line, the whole voyage will be nearly $10698 \mathrm{~nm}$ with Google Earth and BLM Shipping. However, through the NEP, the voyage can be shortened to $7644 \mathrm{~nm}$.

The NEP has shortened the voyage and time for sailing. In other words, it can increase the number of trips. That is to say, we can increase the cargo in the same period. The decrease of voyage will bring the fuel cost down. But we should figure out that the passage cost of NEP is higher than that of Suez Canal because that the NEP needs the assistance of icebreaker. Thus we can increase the economic efficiency of the route by cutting down the passage cost of NEP.

Based on the reality of China-EU trade, what can be expected is that China-EU trade container transport through the NEP would be more economic and reasonable than traditional Suez. In the future, as the Arctic melting is speeding, navigation period will be extended, and the application of the new technology makes ship ability of breaking ice of increase. The NEP's economical advantage will be even more significant.

The opening of the NEP will bring huge economic potential which has a positive impact on ocean shipping between China and Europe. The ship could avoid off the coast of Somalia, the Strait of Malacca, the Suez Canal and other high-risk areas to improve the security and efficiency of shipping. In addition, under the background of shipping in the EU carbon tax, it also can effectively reduce carbon emissions, but it is likely to be threats to the fragile ecological environment in North Pole.

\section{The Influence of the Arctic Navigation on the Import of Crude Oil}

With the rapid development of economy, China needs plenty of energy supply. As domestic crude oil production is stagnant, China's crude oil import dependency is rising. According to the "domestic and international oil and gas industry development report, 2013", China's oil import dependency reached $58.1 \%$ in 2013 . The international energy agency predicts that by 2035 more 
than $80 \%$ of oil supply in China will rely on imports [4], and more than $85 \%$ need to rely on the way of shipping. Chinese customs released data show that in 2013 China has imported 282 million tons of crude oil. The main source of imports of crude oil and the number are shown in Table 1.

Table 1 China's major source of imports of crude oil and the number (Units: ten thousand tons)

\begin{tabular}{|c|c|c|c|c|c|c|c|c|c|}
\hline $\begin{array}{c}\text { Import source } \\
\text { countries or } \\
\text { regions }\end{array}$ & 2011 & 2012 & 2013 & $\begin{array}{c}\text { Average } \\
\text { in } \\
2011-2013\end{array}$ & $\begin{array}{c}\text { Import source } \\
\text { countries or } \\
\text { regions }\end{array}$ & 2011 & 2012 & 2013 & $\begin{array}{c}\text { Average } \\
\text { in } \\
2011-2013\end{array}$ \\
\hline Asia & 16546 & 17423 & 18619 & 17529 & Africa & 5978 & 6388 & 6039 & 6135 \\
\hline Saudi Arabia & 5028 & 5391 & 5390 & 5270 & Angola & 3115 & 4016 & 4001 & 3711 \\
\hline Iran & 2775 & 2202 & 2144 & 2374 & $\begin{array}{c}\text { The republic } \\
\text { of Congo }\end{array}$ & 563 & 537 & 708 & 603 \\
\hline $\begin{array}{c}\text { Russian } \\
\text { federation }\end{array}$ & 1972 & 2433 & 2435 & 2280 & Sudan & 1299 & 251 & 246 & 599 \\
\hline Oman & 1815 & 1957 & 2548 & 2107 & Libya & 259 & 731 & 240 & 410 \\
\hline Iraq & 1377 & 1568 & 2352 & 1766 & Algeria & 217 & 257 & 184 & 219 \\
\hline Kazakhstan & 1121 & 1070 & 1198 & 1130 & $\begin{array}{c}\text { Equatorial } \\
\text { Guinea }\end{array}$ & 176 & 200 & 243 & 206 \\
\hline Kuwait & 954 & 1049 & 934 & 979 & Egypt & 104 & 77 & 125 & 102 \\
\hline $\begin{array}{c}\text { The United } \\
\text { Arab Emirates }\end{array}$ & 674 & 874 & 1028 & 859 & Nigeria & 84 & 94 & 105 & 94 \\
\hline $\begin{array}{c}\text { Republic of } \\
\text { Yemen }\end{array}$ & 310 & 358 & 245 & 304 & Congo gold & 37 & 85 & 111 & 78 \\
\hline Malaysia & 171 & 111 & 60 & 114 & Cameroon & 47 & 58 & 0 & 35 \\
\hline Vietnam & 85 & 74 & 65 & 75 & Gabon & 17 & 31 & 48 & 32 \\
\hline Qatar & 71 & 100 & 13 & 61 & Chad & 32 & 28 & 14 & 25 \\
\hline Indonesia & 57 & 55 & 68 & 60 & Mauritania & 28 & 23 & 14 & 22 \\
\hline Thailand & 33 & 72 & 59 & 55 & $\begin{array}{c}\text { CENTRAL \& } \\
\text { SOUTH }\end{array}$ & 2313 & 2740 & 2759 & 2604 \\
\hline Mongolia & 29 & 50 & 61 & 47 & Venezuela & 1152 & 1529 & 1575 & 1419 \\
\hline Brunei & 61 & 40 & 0 & 34 & Brazil & 671 & 608 & 525 & 601 \\
\hline Azerbaijan & 13 & 19 & 19 & 17 & Columbia & 223 & 291 & 394 & 303 \\
\hline other & 468 & 438 & 343 & 416 & Mexico & 169 & 102 & 110 & 127 \\
\hline Canada & 60 & 66 & 40 & 55 & Argentina & 44 & 121 & 84 & 83 \\
\hline Australia & 408 & 372 & 303 & 361 & Ecuador & 54 & 89 & 71 & 71 \\
\hline
\end{tabular}

Data sources: China's customs statistics yearbook (2011-2013) and the customs information network (http://www.haiguan.info/)

The data in Table 1 shows that China's crude oil imports are mainly from Asia, Africa, Central and South America. Except for few regions such as Russia and Kazakhstan which transport through pipeline and rail, most of the regions transport by sea.

According to China's crude oil import source, the countries with close geographical position are divided into one area. Source of imports of crude oil can be combined into seven areas, which are the Persian Gulf region, North Africa, Middle East, West Africa, Southeast Asia, North America, Central and South America, Australia.

The opening of the NEP, not only makes the imports of crude oil from the North Sea and the Arctic Circle come true, but also opens up a new oil imports line for China. Compared with the traditional Suez, the NEP distance is shortened by almost a third, while compared with the Cape of Good Hope route, the Arctic routes distance is nearly the half [5]. The distance shortened will inevitably bring sharply lower shipping costs, and reduce sailing time, the cost of staff and operational management.

At present, crude oil imports line's safety problem has become a major problem for China's economic security. Most of China's crude oil is imported through the Malacca Strait. There are a 
large number of ships transporting through the narrow strait every day. Once blocked or cut off, it will have great influence on China's oil supply. Moreover, China's crude oil import is mainly from the Middle East, Africa, and Latin America. These country's regions are instability. There are a lot of uncertainties. These uncertainties and volatility caused by geopolitical will inevitably affect China's energy security.

The Arctic oil potential reserves accounts for $13 \%$ of the world, about 90 billion barrels [6, 7]. And at the end of 2012, Sinopec bought $49 \%$ stake in projects of the UK subsidiary of Canadian Talisman Energy Company [7], which marks that the Chinese energy companies began to enter into the investment and development of North Sea oil and gas resources. The opening of the NEP makes it true for China to import crude oil from the Arctic Circle and the North Sea. The Arctic Circle and the North Sea became a new source of China's crude oil imports. This will change the structure of oil imports routes for China and the Far East, and will produce a great impact on the pattern of crude oil shipping in the world.

\section{The Influence of the Arctic Navigation on Bulk Cargo Shipping}

The future transportation of bulk shipping through the Arctic passage will mainly focus on NWP. In 2008, a cargo ship named "The MV Calnilia Desgagnes" first successfully shipped through NWP [9]. As a turning point in recent years, the amounts of bulk shipping increase gradually. For example, in 2013, an ice class bulk carrier "MV Nordic ORION", which belongs to the Danish company Nordic Bulk Carriers A/S, carried 73500 tons of coal from Vancouver to Finland, carrying 25 percent more than that of panama route. On September 19, 2014, a commercial ship named "Nunavik" carrying nickel concentrate, which is owned by Canada's largest ocean shipping company Fednav, successfully arrived at China through NWP [10]. It becomes the first commercial vessel shipping fully independently through NWP. At present, NWP is the shortest passage between the Atlantic and Pacific oceans. Although it is difficult to pass, once opened, the distance between East Asia and the east coast of the United States will be about $2000 \mathrm{~nm}$ shorter than the Panama Canal. And the whole process of the NWP will be more convenient than the small bridge transportation on the west coast of the sea.

There are abundant coal resources in the Arctic region. The total reserves could be 1 trillion tons, and the coal quality is excellent. There also are some other mineral resources with high quality in the arctic. For example, the United States in northern Alaska Kurtz cloth red dog is world-class precious metal production area. Canada's Prince of Wales Island contains large number of plutonium ore. The Arctic shipping will help these resources more smoothly shipped out.

Although the Arctic routes have higher request for bulk cargo ship form and the crew's overall quality than traditional routes, but its advantage in mile and economy will affect bulk cargo transportation pattern. In the Far East- east coast of North America, bulk trade NWP also has a certain potential.

In conclusion, once the Arctic routes realize all-year navigation, there will be an important influence on China's international shipping structures and the world shipping pattern. It shortens the distance and sailing time, reduces the fuel cost, and brings the huge economic potential which has a positive impact on the shipping between China, Europe, and eastern parts of America. With the further melting of the Arctic ice, assisting navigation's cost can be reduced or even canceled. And with the rapid development of navigation technology, the shipbuilding technology, the Arctic routes will be the important link among China, the United States and central Europe. China should fully grasp the business opportunities, adjust structure, and promote the development of China's foreign trade.

\section{Acknowledgements}

This work was supported by national natural science foundation of china (NO.61473053) and the Social Science Fund of Liaoning Province (Grant No. L15BJY041). 


\section{References}

[1] R.G. Arctic: Research on the Arctic issue (Ocean Press, China 2011). (In Chinese)

[2] X. Zhang and Q.A. Zhao: Navigation of China, Vol.38 (2015) No.1, p.102. (In Chinese)

[3] W.Z. Xu: World Shipping, Vol.37 (2014) No.2, p.20. (In Chinese)

[4] M. Qi, O.B. Marco and S.Q. Fan: Resources Science, Vol.36 (2014) No.3, p.512. (In Chinese)

[5] A.F. Zhang and Y.P Song: Journal of Dalian Maritime University May, Vol.40 (2014) No.2, p.43. (In Chinese)

[6] Z.R. Bai, M.Y. Li and G.F. Yang: Petroleum and Petrochemical Today, (2011) No.9, p.39. (In Chinese)

[7] Y.M. He and C. Zhou: Resources Science, Vol.35 (2013) No.8, p.1651. (In Chinese)

[8] M.X. Zhang: China Special Equipment Safety, Vol.28 (2012) No.9, p.65. (In Chinese)

[9] Information on http://yeship.com/news/1255713.html

[10] Information on http://www.eworldship.com/html/2014/OperatingShip_0922/92694.html 